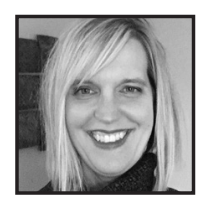

\title{
"Just" Teaching: Linking Teacher Identity to Community and Practice
}

\author{
Sarah Trask, University of Saskatchewan
}

\begin{abstract}
Classroom communities in Saskatchewan are becoming increasingly diverse. Given that teachers may differ in race and class from many of the students whom they teach, the author asserts that teachers benefit from an exploration of the social construction of their identity. She tells stories of her experiences as a teacher on the school landscape in order to foreground her positioning and to interrogate wellmeaning fumbles that she has made. Providing recent and relevant examples in a Canadian context, the author examines the consequences of social stratification, such as deficit thinking by teachers and institutional racism in schools. She concludes that making the exploration of identity central in teacher education has the potential to promote authentic community in schools and classrooms.
\end{abstract}

\section{Context}

"Who are you?" "Where do you work?" "What did you do this weekend?"

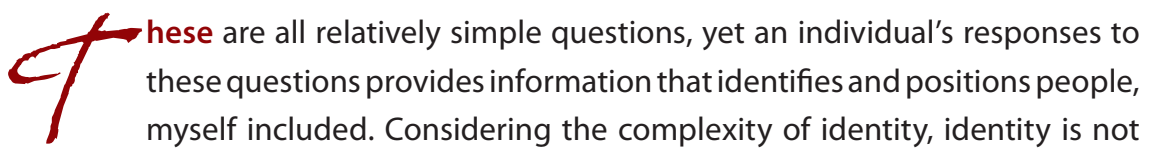
just a noun but it is also a verb. I can identity myself; reciprocally, others identify me. How do I see myself? How do I want others to see me? 
As Saskatchewan schools become more diverse, teachers are called to teach children of varying community backgrounds. Demographics in Saskatchewan have changed dramatically in recent years due to government programs and an influx of refugee families (Anderson \& Tilbury, 2014). The population of students for whom English is an Additional Language (EAL) has risen to $20 \%$ of the total enrollment in the Saskatoon Public School Division as of 2013 (Anderson \& Tilbury, 2014). As of 2006, 27\% of Saskatchewan children, aged zero to four years of age are First Nations and Métis (Saskatchewan School Boards Association, 2007). Race and social class vary widely and contribute to classrooms of rich diversity. Teachers are challenged to explore their own identity in order to further understand their students. Perhaps when we, as teachers, understand how race and class influence identity in ourselves, we will be more wakeful to the disjuncture which students are confronted with in classroom and school communities.

In this paper, I define the complex construction of identity in relation to race and class. I also shares stories of my lived experiences on the school landscape, providing me with the opportunity to examine my positioning in relation to the children and families with whom I have worked. I examine the consequences of social categorization which result from such actions as deficit thinking by educators and institutional racism in schools. Using critical multiculturalism as a lens, I present possibilities within teacher education to address and challenge current notions of teacher identity.

\section{The Little Girl From "Uniformity"}

For the purposes of this paper, Uniformity will be used as a pseudonym for my hometown. I grew up in a small town in Saskatchewan with a population of 1,000. As a child, I could hear coyotes and crickets in the evenings and various church bells ringing on Sundays. On sleepovers or play dates, I would play hide and seek outside with friends, hiding behind bales or within ripe wheat fields. When I asked my mother if I could go to "the rink" or "the store," my mother knew exactly where I would be. In this small community, everyone was different, yet we were all so much the same. There was little income disparity between families; we all had enough. Holly Hobby and Strawberry Shortcake were popular cartoon characters in the early 1980s; these characters were commonly found on backpacks and lunch kits. My friends and I would open our blue Holly Hobby or pink Strawberry Shortcake lunch kits to find sandwiches on homemade bread, probably with leftover meat from supper the 
night before. If I was really lucky, there would be packaged cookies for dessert. Homemade baking was common so a bag of Dad's Cookies was a treat. We all had winter coats and boots, with mittens attached to a string.

Attendance at school was a priority for families, with certain caveats. Even when it was so cold that the buses were not operational, farm children would often arrive at school via snowmobile or tractor. Other than illness, there were two exceptions to our nearly perfect school attendance. During seeding or harvest, boys who were old enough to help on the farm would stay home to do so. I used to envy the farm boys just for that reason. The other exception to school attendance was Ukrainian Christmas. If your family celebrated Ukrainian Christmas, you stayed home. It was as simple as that. My family and I were often invited to partake in these elaborate meals each year. We enjoyed pierogis and cabbage rolls, painstakingly handmade for these celebrations, marked by the Julian calendar. I am confident that the school did not contact parents to inquire as to the students' whereabouts around these occasions. Farming seasons and the Julian calendar were community norms; we all understood. My idea of diversity was the block of exotic mozzarella cheese which my mother would purchase in order to make lasagna.

This snippet from my childhood illustrates my white, middleclass-ness, and my taken-for-granted rural norms. I lived in a community in which disparity and diversity were minimal. Everyone around me was white and spoke English. I did not have a non-white student in my class until the end of high school. Dimensions of class were close to uniform as well. Some families had less financial means than others, but those families had three solid meals a day and lived in clean, secure, and maintained homes. Many families had income that allowed for a cabin at the lake and/or a snowmobile. Everyone was connected to a farm, being actual farmers or providing service to farmers. Although I recognize that individuals are unique and each family likely had their own special identity as a unit, Uniformity was a place in which we were more similar than different. These formative years established my sense of "normal" and "typical." When I left home and began teaching, I was heavily influenced by the norms engrained through my experiences as a youth in Uniformity.

\section{Identity: Under Construction}

There have been many theorists and researchers who have provided definitions of identity. For example, Vygotsky (as cited in Olsen, 2008) stated that identity is 
"a dynamic process of individuals developing conceptions of themselves as rational beings over time" (p. 4). Gee (as cited in Akkerman \& Meijer, 2011) added to that definition, saying that identity is the type of person one is recognized as being in any given context relating to one's inner self and one's performance in society. In Gee's definition, identity is both individual (inner self) and collective (performance in society). Burke and Stets (2009) extended that definition further, stating that identity is a set of constructions that clarify who one is when occupying a particular role in society and as a member of a specific group, as well as owning the characteristics which contribute to the uniqueness of oneself. To make this more concrete, stating that "I am a teacher," identifies my role in society. My characteristic of white skin identifies me as a descendant of European ancestry, a member of a specific group. Holding proudly to the belief, "I am trustworthy," defines my ownership of a personal characteristic of note.

Jenkins (2004) expressed that all human identities are social identities, stating, "Identifying ourselves or others is a matter of meaning, and meaning always involves interaction: agreement and disagreement, convention and innovation, communication and negotiation" (p. 4). He continued by stating his belief that the term "social identity" is redundant in nature, preferring instead to use the term "identity." Jenkins asserted that similarity and difference are the criteria required within the process of identification. Each individual considers how s/he is similar to someone or something and simultaneously identities her/himself while being identified by others.

As individuals live in the world, they do so in ways that develop, validate, and protect their sense of identity (Burke \& Stets, 2009). In Uniformity, I was white like everyone else. Identity inscription involved being Ukrainian or not being Ukrainian. During my childhood, most of the people in Uniformity were Ukrainian; my family was not. However, I identify myself and was likely identified as an honorary Ukrainian. I was surrounded and immersed in rich Ukrainian cultural practices by people who maintained their language, food, and dance. I always felt welcome to participate and enjoyed aspects of Ukrainian heritage, everything from consuming the little cabbage rolls to learning various Ukrainian words. I must confess I learned to curse in Ukrainian at a young age! As an adult, I continue to share the Ukrainian Christmas greeting and try to return to Uniformity each year to celebrate Ukrainian New Year's, Malanka, in accordance with the Julian calendar. Without conscious thought, I maintain and protect my identity as an honorary Ukrainian from Uniformity. 


\section{Class: A Construct of Identity}

Class is a central construct of one's identity. Block (2012) credits Harriet Bradley with providing a concise definition of class:

Class is a social category which refers to lived relationships surrounding social arrangements of production, exchange, distribution and consumption. While these may narrowly be conceived as economic relationships, to do with money, wealth and property...class should be seen as referring to a much broader web of social relationships including, for example, lifestyle, educational experiences and patterns of residence. Class, therefore, affects many aspects of our material lives. (p. 189)

I originally thought that class was exclusively and overtly about income. However, Bradley's definition of class expanded my thoughts. For example, her definition refers to consumption, which could be the store one patronizes as an indication of class. Asking an acquaintance where she purchased her new dress is different than asking her about her household income. However, her response provides information which I identify with socioeconomic class.

As I considered facets of class, I was led to Pierre Bourdieu and his work regarding habitus and types of capital. Bourdieu (as cited in Block, 2012) stated that habitus is a set of dispositions which form present and future thoughts and actions, as individuals navigate various fields. Bourdieu identified fields as social arenas such as education or sports, in which an individual adapts and flexes in order to achieve a powerful position. A person's position is reliant upon his or her types of capital in comparison to the capital of others. Block (2012) emphasized that class positioning extends beyond material wealth and includes social and cultural capitals. For example, symbolic behaviour such as how one dresses and hobbies in which one partakes are facets of class. Class is an "identity inscription" (p. 189).

In Uniformity, socioeconomic class varied only to a small degree. In hindsight, I see that my family had more financial capital than some other families. For example, I travelled on an airplane several times as a child. However, families with less financial capital had a garden full of vegetables and, likely, half a beef in the deep freeze. My friends and I had access to quality food and to a large quantity of food. I do not believe that anyone at that time, in that place, went hungry. In fact, food was a form of capital. Community organizations frequently provided meals as fundraisers, requiring purchased tickets. As a member of an organization, one could donate money 
to contribute to the meal or donate hours of time and ingredients in order to provide homemade casseroles, soups, or desserts.

Other types of capital at the time were the number of combines or grain bins owned by individual farmers. Extensive farm equipment identified a farmer who was "doing well" or had a "big operation." Shiny new snowmobiles and restaurant meals in "the city" were also considered forms of capital. These leisure pursuits identified one's financial means and one's worldliness, "Have you been to Earl's...l love their Kung Pao"!

\section{Race: Construct of Identity}

Just as class is central to one's identity, so is race. Winant (2000) stated that race is a "concept that signifies and symbolizes sociopolitical conflicts and interests in reference to different types of human bodies" (p. 172). Fifteen years later, Winant (2015) added that race is a type of ethnicity, a shared belief of cultural practice which becomes norms for the community. Zuberi, Patterson, and Stewart (2015) asserted that, "race rests on the experience of shared social relations rather than a unitary (i.e. individual), shared subjective characteristic such as skin color" (p. 110). Race manifests a social process which uses racial classification to develop and reinforce inequitable social interactions. "[T] hese phenotypical differences (ie. racial classifications) represent cues that the social structure has used to order, distinguish, and exclude certain groups and, subsequently, produce real differences in social opportunities and outcomes" (Bonilla-Silva; Brody et al.; Kuzawa and Sweet; Miller et al.; Stetler, Chen and Miller; Stewart as cited in Zuberi, Patterson and Stewart, 2015, p 110). These researchers provide a vivid portrayal of race as a social construction. I had always considered race in relation to phenotypical characteristics. However, as I begin to understand race as a social construction, I ponder opportunities, access, and relationships for students of varying races within the structure of education.

I have begun to believe that the understanding that race is a social construction is pivotal for teachers to understand. For instance, Hunter, Friend, Williams-Wheeler, and Fletcher (2012) stated that racial preferences and racial attitudes influence formation of friendships in children as well as their parents. Race is a powerful belief system within one's individual and collective identity which serves as another way to classify and categorize oneself as well as one's peers. Racial identity can be defined as the "significance and meaning that individuals contribute to race" (Sellers, Smith, Shelton, Rowley, \& Chavous, 1998 as cited in Neblett \& Roberts, 2013, p. 943). When I was in high school in Uniformity, a First Nations student joined our class. 
His family had moved to our community from another province over the summer. I do not think he knew a soul in Uniformity on that first day of school. He was kind and soft-spoken, and he rapidly made friends. He became a good friend of mine. At the time, I did not stop to consider how he may have felt, though, connecting with our white selves. How was he made to feel welcome? What feelings may have he experienced as a newcomer? In what ways was he conscious of his race? I realize now, years later, the courage that those first few days of school required of him. What was it like to walk into a classroom of white kids, with established friendships, knowing each other since toddlerhood, as a First Nations student from out of province?

\section{Intersection: Race and Class Are Not Mutually Exclusive}

Race and class are not mutually exclusive; they intersect and influence each other. Robinson (1999) noted that identities are not neutral, "Identities possess rank, have value, and are constructed hierarchically, particularly those that are visible and discernible" (p. 73). Given that identities have rank, what are the consequences? Jenkins (2004) stated that, "one of the things we have in common is our differences from others" (p. 91). People classify and categorize each other through social constructions such as race and class. We recognize and are drawn to similarities as these similarities provide a sense of belonging and validation.

Hunter and colleagues (2012) conducted a qualitative study in which they interviewed mothers about their social networks and those of their children, in relation to race, class, and religion. The researchers were curious if and how children's friendships crossed these boundaries and how their mothers interpreted these friendships. The researchers found that as the mothers considered their children's relationships, social comparisons were made within a Self/Other construct (Hunter et al., 2012). While most mothers responded that neither they, or their children, saw "color," the children's inter-racial friendships did not extend to their parents. Further, social class also came into play as middle- to upper-class parents expressed concern about their children being exposed to the perceived dangers of the lower class. One parent stated, "I would not want them [her children] in an environment where there was a lot of, you know, real vulgar language, or even drinking" (p. 463). This study illustrates the potential influences as race and class intersect among children and their playmates. As parents perceive differences of race and class within the social connections of their children, they make judgments to protect and preserve identity inscriptions which are similar to their own. 
Block (2012) provided another such example of the intersection of race and class as he unpacked a recorded conversation involving a man named, Carlos. Carlos, a Columbian living in England, with "middle class modes of behavior" (p. 201), noted that when his colleagues discussed Columbia, they made stereotypical references to drug trafficking and poverty. He felt his "otherness" (p. 201) because his racial difference was identified through negative stereotypes by his colleagues. "Other" is used as a noun or verb to describe someone or something different than oneself. Turner-Vorbeck and Marsh (2008) cited Madrid as stating:

Being the other means feeling different; is awareness of being distinct; is consciousness of being dissimilar. It means being outside the game, outside the circle, outside the set. It means being on the edges, on the margins, on the periphery. Otherness means feeling excluded, closed out, precluded, even disdained and scorned. It produces a sense of isolation, of apartness, of disconnectedness, of alienation. (p. 2)

When I think about the notion of othering, I think about how easy it is to other, when an individual is always on the inside of the circle. I grew up without exposure to diversity or disparity. As a young woman completing my undergraduate degree, I made friends with other white middle-class kids from small towns. I have never felt disconnected or isolated from my peers or neighbors. It is easy to "other" when you are not the other. I would say it is subconscious to other when you have a comfortable position on the inside.

Considering the intersection of race and class in one's identity development, and in relation to the significant numbers of First Nations and Métis peoples in Saskatchewan and our rapidly increasing population of immigrant and refugee children and families, I am drawn to wonder how different the experience of school must be for a non-white child living in poverty compared to the experience of a white, middle-class child. Further, I recall that as a child, my teachers were white and middle class. As a professional, most of my colleagues have been white and middle class. What happens when there is incongruence between the lived experiences of children and teachers? How are teachers' unconscious or unchallenged beliefs and assumptions about children embodied on a school landscape? 


\section{The Little Girl From Uniformity in the Big City}

I was assigned to teach Kindergarten at St. Disparity Community School in Prince Albert, Saskatchewan for my first teaching position. Prince Albert is a city smaller than Saskatoon, approximately 140 kilometres north. I choose "St. Disparity" as a pseudonym for this school for good reason. The community in which the school was located had a significant income disparity between two distinct populations. There were white students (about 50\%), most of whom had been to preschool before Kindergarten. These children came from middle-class homes and were involved in lessons such as soccer or dance. In addition, approximately $50 \%$ of the students were First Nations or Métis, most of whom were living in contexts of poverty. Because of this context, these children often did not have lunch or winter mittens and, typically, Kindergarten was their first school experience. A few of my First Nations students had recently moved to Prince Albert from a community located approximately 900 kilometres north of our small city and spoke only their Dene language.

As a young teacher, I knew on an intellectual level what poverty was but I had never seen it until then. Young children tend to share a great deal and I heard stories of addiction, domestic violence, and incarceration. One of my Kindergarten students told me that sometimes her dad had a "hoot," "you know, those hoot smokes." Another shared that she wore shoes at night so that she would not step on broken glass if she had to get up in the dark. I taught children who had not had breakfast and who had never seen a dentist. Given the different life experiences of the children living in a context of poverty and those living in white, middle-class homes, there was disparity in their achievement in school. I confess that at times I thought that the lack of achievement of my minority students was due to their home environments. When I considered the variation in the children's experiences coming into Kindergarten, I determined that the kindest thing to do as a teacher was to have lower expectations for the children living in contexts of poverty. In hindsight, I wonder how I would have made sense in that moment if the white middle-class students were struggling with achievement. Would I have placed responsibility on their homes or would I have looked towards the school system, and teaching practices? What beliefs and assumptions were underpinning my decision to lower my expectations for some of my students? 


\section{Consequences of Social Categorization: Institutional Racism and Deficit Thinking}

I easily connected with the white middle-class families at St. Disparity and recall visiting with those parents at drop-off times. Sometimes, I would encounter these families in the community as we would be at the same restaurant or salon. At the same time, I felt self-conscious when speaking to non-white, low-income parents as I was aware of our differences and I did not want to appear pretentious or racist. At times, I struggled to make small talk as I was trying so hard to connect that I could not relax. I did not feel that I could be myself. Henry and Closson (2008) conducted a study on a college campus in the United States. They interviewed students in mono-racial focus groups to discuss perceptions about white students attending the campus of predominantly black students. A white research participant, Carl, felt that he could not be what he saw as his normal self as his normal may offend someone on the black campus (Henry \& Closson, 2008). I must admit that I felt somewhat like Carl. For me, relationships with children have always been easier and simpler to form than my relationships with adults. While teaching Kindergarten at St. Disparity, I desperately wanted to provide warmth and openness in my relationships with all parents, but I recognize that I probably never achieved it. I was definitely more comfortable dealing with adults who were more like me; it was easier. How was I subconsciously judging the families who were unlike my own? Beyond my self-consciousness, I must admit I was making some judgments based on my identity and what I considered to be "normal," given my own lived experiences. These judgments led me to see deficits in families and home environments as reason for their children's lesser achievement.

Deficit thinking. What are the consequences when teachers identify and categorize students according to race and/or class? One of the consequences is deficit-thinking on the part of teachers. "Deficit thinking theory blames school failure for these students on the students' lack of readiness to learn in the classroom, the parents' lack of interest in their education, and the families' overall lifestyle" (Walker, 2011, p. 577). Through the position of deficit thinking, teachers see themselves as not responsible nor required to change practices or policies to meet needs of minority students. In a study by Massey, Scott, and Dornbusch (1975), the researchers discovered that teachers had lower expectations for black students than non-black students in academic environments in San Francisco high schools. Although they were kind to the black students, they did not provide them with challenging assignments. They concluded, "We have shown that oppression can arise out of warmth, friendliness and concern" (p. 18). This study reminds me of my time at St. Disparity. I had lower expectations for minority children living in contexts of poverty. While my expectations originated 
from a place of genuine love and concern, they were disadvantaging many of my students and contributing to an ever-widening gap in achievement between the races and classes represented in my classroom.

Institutional racism. When deficit thinking becomes ingrained within the practices of an institution, it leads to institutional racism. A recent Canadian example of such institutional racism is detailed in the British Columbia (BC) Auditor General's report, Racism of Low Expectations (2016). An interview on The Current with Anna-Maria Tremonti (2016) of CBC Radio and Sheila Dodds, the Assistant Auditor General of BC, revealed that some First Nations students who are not special needs have been receiving an "Evergreen Certificate." Dodds explained that the Evergreen Certificate is a certificate of completion for students with special needs, incapable of completing the regular high school program. Glen Hansman of the BC Teachers' Federation noted that the Evergreen Certificate is not recognized at postsecondary institutions. He explained that the staff involved thought, "Oh these kids won't make it all the way, or you know this is their best chance to have a piece of paper in their hands before we send them off" (para. 10). Dodds asserted that this example of institutional racism reflects a "preconception or a bias that stems from social attitudes" (para. 4). As First Nations students complete high school with a certificate not accepted by postsecondary institutions, their choices for their futures are therefore limited. As I noted earlier in relation to Bourdieu's work, individuals navigate arenas such as education for positions of power. The practice of institutional racism, therefore, in which Evergreen Certificates are given to First Nations students, protects the position of power occupied by the white middle-class students who are graduating with recognized high school certificates.

Hidden curriculum. I wonder also about the hidden curriculum and its impact in this area. Hidden curriculum is not explicit curriculum, but rather identifies the norms of schooling (Moroye, 2009). For instance, we implicitly teach children what to share and discuss by discussing or avoiding certain topics. As a child in Saskatchewan, I was implicitly taught to gloss over the history and legacy of residential schools. In Uniformity, I knew of a neighboring town which had operated a residential school at one time. I did not fully understand what the term "residential school" meant; it was neither taught nor discussed. All I recall hearing about residential schools, from my surrounding network of white middle-class adults, was that "native kids used to live there." In their defense, perhaps they did not fully understand either. If residential schooling was never a topic for authentic discussion, people of any age would not understand. "The glossing over of the negative implications/connotations of the comments reflects the socially determined and acceptable responses to racial 
issues that has been constructed for centuries in America" (Liggett, 2008, p. 392). I consider this to be an example of implicitly teaching children to reproduce social constructions of inequality by glossing over or not acknowledging injustice.

Daigle (2000) examined the taken-for-granted practices associated with white teachers of First Nations students in New Brunswick. One of the taken-for-granted practices she identified was that discussion of racism was restricted to discussion of overt acts. I would agree as a practicing teacher that overt acts of racism are likely what children and adults associate with the term racism. She admitted, in contrast to the overt, "I often blamed the home environment and the social conditions of Other for the academic difficulties they encountered" (p. 103). In moving backward in time to unpack her blaming behavior, she acknowledged that, "it is much more difficult to detect racism which is covert, institutionalized and societal in nature" (p. 48). Racial comments in classrooms are often minimized by white teachers because "being white can make issues of race seem exaggerated" (Delpit, as cited in Liggett, 2008, p. 394). When I think back to my years at St. Disparity, I believed in the principles of equality, yet I had different expectations of my students within the binary population which I served. Although I would have recognized overt acts of racism, I did not consciously recognize the dominance of white middle-class norms and the covert message of superiority. I do not recall, but I humbly acknowledge that I may have minimized racial issues as I had never felt "othered"; my lived experiences had been privileged and protected.

In preparation for writing this paper, I noticed the reoccurring connection between white teacher identity and the practice of downplaying or not acknowledging racial comments and issues. How does this affect children's identity development? When our First Nations classmate joined us in Uniformity, he fit right in. That being said, throughout our friendship in high school, I never did know which First Nation he was from. He did not say and I did not think to ask. Why did he not feel comfortable to share his race and background? How was his identity development affected by not discussing it? I think also of children as newcomers to Canada who are in Saskatchewan classrooms. How are they given the opportunity and the safety to share and discuss their identity? 


\section{Implications for Teacher Education}

As I reflected upon the complex constructions of identity, and examined the intersections between race and class in school classrooms, I have foregrounded potential consequences that can arise, such as deficit thinking and institutional racism, when teachers are not awake to their own identity and to the beliefs and assumptions which underpin that identity. What aspect of teacher education will enable teachers to understand the complex challenges students face in classrooms? What might be done in teacher education to prepare teachers to meet the needs of all of their students in an equitable, genuine fashion? The first step may be to engage preservice teachers in activities which bring them to recognize their own positioning and their own identity. Palmer identifies authenticity as a journey and a quest for identity, a "moving intersection of the inner and outer forces that make me who I am" (as cited in Leonard, 2006, p. 2).

I am a white girl from Uniformity, Saskatchewan; I had a privileged childhood. As an adult, I work in the Saskatchewan education system. I have thus been in the Saskatchewan education system since I was four years old. I identify, and undoubtedly would be identified, as white middle class. Given my lived experiences, and without teacher education to interrupt the beliefs and assumptions I have formed as a result of those experiences, how might I understand the complex social dynamics and social constructions affecting students and families whom I serve? The truth is that it has taken me a Master's in Education and nearly 20 years of teaching to begin thinking about and reflecting upon any of these issues. Clandinin and Connelly (2000) define ongoing reflection as wakefulness. Leonard (2006) believes that the journey of authenticity requires a level of wakefulness. I agree whole-heartedly with Palmer and Leonard as I reflect on my own journey of authenticity. Perhaps there are ways to expedite this process and encourage a wakefulness within teacher education programs. 


\section{Critical Multiculturalism}

How might the inclusion of curriculum on critical multiculturalism begin to encourage such a wakefulness?

\section{Critical multiculturalism}

includes the following features (1) Recognizes the socio-historical construct of race, and its intersections of class, gender, nation, sexuality and capitalism; (2) creates pedagogical conditions in which students interrogate conditions of "otherness"; (3) challenges the idea of social work (and other social sciences) as an apolitical, trans-historical practice removed from the power struggles of history; and (4) makes visible the historical and social construction of whiteness. (Nylund, 2006, p. 30)

Schoorman (2012) said that critical multiculturalism belongs in early childhood teacher education. Freire (as cited in Schoorman, 2012) stated that education "can be used for both oppressive and liberatory purposes" (p. 241). Students of teacher education programs would ideally learn and understand social constructions such as race and class as well as the resulting power structures. Spring (as cited in Schoorman, 2012) argued that current and historical patterns in education serve to marginalize non-mainstream groups. I would suggest that the reciprocal effect of marginalization protects the mainstream. In order to develop wakefulness of power structures in education, teacher candidates may consider their own role and positioning. "[F]or preservice teachers and inservice teachers to become critically conscious, justice-oriented practitioners, it is imperative that teacher educators facilitate the conditions for this transformation" (Schoorman, 2012, p. 342).

Schoorman (2012) developed an assignment for students of teacher education in which they explore and construct their respective cultural profiles. These students are encouraged to consider the various pieces of their identities, how they have been socialized and the implications of their positioning in relation to multiple perspectives. I find this assignment powerful and poignant. As stated earlier, I did not recognize myself to be in a position of privilege until half way through my teaching career. The opportunity to explore the complex constructions of identity has created a wakefulness in me that was not there before. An assignment such as Schoorman's cultural profile during my undergraduate program may have increased my awareness of social constructions as a young, new teacher. I may have felt less awkward with families unlike my own. I may have made more of an effort to consider diverse perspectives and to develop relationships with families different from my own. 
Further, inclusion and integration of students' backgrounds would enhance and empower identities. Grade 1 Curriculum in Saskatchewan requires children to learn about traditions, celebrations, and stories of individuals in the classroom and in the school. In my experience, teachers invite families to send food or books which reflect their identity. While I agree that food and books are an engaging starting point, I believe that food and books merely scratch the surface. Schoorman (2012) stated that children would benefit from opportunities to explore differences as "non-threatening, enriching, and normal" (p. 343). Schoorman said that teachers can accomplish this by not assuming that families have books to bring to school and not dictating that children should be read to every evening. Instead, Schoorman suggested that families can create their own texts which children can read to family members. These texts could be bilingual and provide context for children to explore and develop literacy skills. I love the idea that children can take pride in their own texts as well as enjoy exploring their classmates' projects. I believe that such a literacy endeavor probes beneath the surface of multicultural education and reaches a deeper, more authentic level of empowerment and richness.

\section{Conclusion}

In this paper, I have presented identity as a social construction of inscriptions such as race and class, inscriptions which intersect with each other, often without distinction. I have humbly shared my well-meaning fumbles when confronted with families unlike my own in order to make visible the consequences of social stratification such as deficit thinking by teachers and taken-for-granted institutional racism in schools. I will always treasure my childhood years in Uniformity, as it was a safe and secure place to grow up. Although a part of me will always be that little girl, I have a wakefulness now that I did not have then. Greene (as cited in Rautins \& Ibrahim, 2011) stated that a critical pedagogy of "wide-awakeness" enables learners to be mindful of oneself and others, creating an opening for mindful interrogation of how the world is constructed in relation to knowledge, power, and inequity. Becoming wide-awake, I realize now that racism can be covert, not just overt. I realize that racism can originate from a place of kindness. It is only with such wakefulness that I can see inequity when it is hidden beneath the surface or covertly built into a structure. I understand that life is not as black and white as I understood it to be when I was a little girl in Uniformity. Sometimes, life is grey and muddy, and I am unable to see with clarity. It is with wakefulness that I can exist within the grey, and do my best to see through it. 


\section{References}

Akkerman, S. F., \& Meijer, P. C. (2011). A dialogical approach to conceptualizing teacher identity. Teaching and Teacher Education, 27, 308-319. doi:10.1016/j.tate.2010.08.013

Anderson, L., \& Tilbury, S. (2014). Initial intake and assessment of EAL learners. Education Matters, 2(1), 88-93.

Block, D. (2012). Class and SLA: Making connections. Language Teaching Research, 16(2), 188-205. doi:10.1177/1362168811428418

Burke, P. J., \& Stets, J. E. (2009). Identity theory. New York: Oxford University Press. doi:10.1093/acprofoso/9780195388275 .001 .0001

Clandinin, D. J., \& Connelly, F. M. (2000). Narrative inquiry. San Francisco: John Wiley \& Sons, Inc.

Daigle, E. (2000). Being a white teacher of native students: Revelations of whiteness in takenfor-granted practices. Retrieved from http:// www.collectionscanada.gc.ca/obj/s4/f2/ dsk1/tape3/PQDD_0028/MQ62119.pdf

Henry, W., \& Closson, R. (2008). The social adjustment of white students in the minority on an historically black college campus. Journal of College Student Development, 49(6), 517-534. Retrieved from http://search. proquest.com.cyber.usask.ca/docview /195182264? OpenUrlRefld=info:xri/ sid:primo\&accountid $=14739$

Hunter, A.G., Friend, C. A., Williams-Wheeler, M., \& Fletcher, A. C. (2012). Race, class and religious differences in the social networks of children and their parents. Youth and Society, 44(3), 450-475. doi:10.1177/0044118X12451798

Jenkins, R. (2004). Social identity. New York: Routledge. Retrieved from http://www. tandfebooks.com.cyber.usask.ca/doi/ view/10.4324/9780203463352

Leonard, P. (2006). Ethics, values and social justice leadership: Embarking on a moral quest for authenticity. International Electronic Journal for Leadership in Learning, 10(30). Retrieved from http://iejll.journalhosting.ucalgary.ca/ iejll/index.php/ijll/article/view/630
Liggett, T. (2008). Frames of reference:The impact of race on teaching strategy and classroom discussion. The Urban Review, 40(4), 386-402. doi:10.1007/s11256-008-0087-9

Malone, K. (2015). National test changes after Saskatoon student notices negative stereotypes about Aboriginals. Retrieved from http://ckom.com/article/219573/nation al-test-changed-after-saskatoon-studentnotices-negative-stereotypes-about

Massey, G. C., Scott, M. V., \& Dornbusch, S. M. (1975). Racism without racists: Institutional racism in urban schools. The Black Scholar, 7(3), 10-19. Retrieved from www.jstor.org. cyber.usask.ca/stable/pdf/41065930.pdf

Moroye, C. M. (2009). Complementary curriculum: The work of ecologically minded teachers. In D. J. Flinders \& S. J. Thornton (Eds.), The curriculum studies reader (pp. 379-398). New York: Routledge.

Neblett, E., \& Roberts, S. O. (2013). Racial identity and automatic responses to racial discrimination. Psychophysiology, 5(10), 943-953. doi:10.1111/psyp.12087

Nylund, D. (2006). Critical multicultural whiteness, and social work: Towards a more radical view of cultural competence. Journal of Progressive Human Services, 17(2), 27-42. doi:10.1300/J059v17n0_03

Olsen, B. (2008). Introducing teacher identity and this volume. Teacher Education Quarterly. Retrieved from www.teqjournal.org/back vols/2008/35_3/05introduction.pdf

Rautins, C., \& Ibrahim, A. (2011). Wide awakeness: Toward a critical pedagogy of imagination, humanism, agency and becoming. International Journal of Critical Pedagogy, 3(3), 24-36. Retrieved from http://libjournal. uncg.edu/ijcp/article/download/

Robinson, T. (1999). The intersections of dominant discourses across race, gender, and other identities. Journal of Counseling and Development, 77, 73-79. Retrieved from http://onlinelibrary.wiley.com.cyber.usask. ca/doi/10.1002/j.1556-6676.1999.tb02423.x/ epdf 
Saskatchewan Curriculum. (n. d.). English Ianguage arts 6 outcomes. Retrieved from https://curriculum.gov.sk.ca/webapps/ moe-curriculum-BBLEARN/index.jsp?view=outcomes\&lang=en\&subj=english_language_arts\&level $=6$

Saskatchewan Curriculum. (n. d.). Social studies 1 outcomes. Retrieved from https://curriculum. gov.sk.ca/webapps/moe-curriculumBBLEARN/index.jsp?view=outcomes \& lang $=$ en \&subj $=$ social\&level $=1$

Saskatchewan School Boards Association. (2007). First Nations and Metis education: An advisory for school boards. Retrieved from http://saskschoolboards.ca/wp-content/ uploads/2015/08/Module_11_FNM_ Education.pdf

Schoorman, D. (2012). Reconceptualising teacher education as a social justice undertaking: Underscoring the urgency for critical multiculturalism in early childhood education. Childhood Education, 87(5), 341-344. doi:10.1 080/00094056.2011.10523210
Tremonti, A. M. (2016). B. C. moves to address 'racism of low expectations' for indigenous students. Retrieved from http://www.cbc.ca/ radio/thecurrent/the-current-for-february -18-2016-1.3453054/feb-18-2016-episodetranscript-1.3454398\#segment1

Turner-Vorbeck, T., \& Marsh, M. (Eds.) (2008). Other kinds of families: Embracing diversity in schools. New York: Teachers College Press.

Walker, K. L. (2011). Deficit thinking and the effective teacher.Education and Urban Society, 43(5), 576-597. doi:10.1177/0013124510380721

Winant, H. (2000). Race and race theory. Annual Review of Sociology, 26, 169-185. Retrieved from http://www.annualreviews.org.cyber. usask.ca/doi/pdf/10.1146/annurev.soc. 26.1.169

Winant, H. (2015). Race, ethnicity and social science. Ethnic and Racial Studies, 38(13), 2176-2185. doi:10.1080/01419870.2015.1058 514

Zuberi, T., Patterson, E. J., \& Stewart, Q. T. (2015). Race, methodology, and social construction in the genomic era. Annals, AAPS, 661(1), 109-127. doi:10.1177/0002716215589718

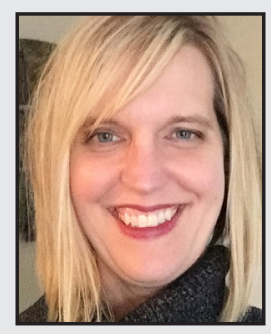

Sarah Trask has been an elementary school teacher for 18 years, serving diverse school communities within Saskatchewan. Her current role is Learning Assistance Teacher in Greater Saskatoon Catholic Schools. Sarah attained a Bachelor of Education degree in 1998 and a Post-Graduate Certificate in Special Education in 2008 from the University of Saskatchewan. She recently completed a Master's degree in Curriculum Studies, also at the University of Saskatchewan. Sarah grew up in a small town and continues to appreciate her rural roots. 